\title{
Retraction Note: Analytical modeling of tensile strength of functionally graded steels
}

\section{A. Nazari ${ }^{1}$}

Published online: 25 August 2020

(C) Springer-Verlag London Ltd., part of Springer Nature 2020

Retraction to: Neural Comput \& Applic (2013) 23:787-799 https://doi.org/10.1007/s00521-012-0995-1

The Editor-in-Chief has retracted this article [1] because it significantly overlaps with a number of articles including those that were under consideration at the same time [2, 3] and previously published articles [4-6]. Additionally, the article shows evidence of peer review manipulation. The author has not responded to any correspondence regarding this retraction.

\section{References}

1. Nazari A (2013) Analytical modeling of tensile strength of functionally graded steels. Neural Comput Appl 23:787-799. https://doi.org/10.1007/s00521-012-0995-1

2. Nazari A (2019) Modeling the correlation between Charpy impact energy and chemical composition of functionally graded steels by artificial neural networks. Neural Comput Appl 31:707-721. https://doi.org/10.1007/s00521-012-1010-6

3. Nazari A, Azimzadegan T (2012) Prediction the effects of $\mathrm{ZnO} 2$ nanoparticles on splitting tensile strength and water absorption of high strength concrete. Mater Res 15(3):440-454. https://doi.org/ $10.1590 / \mathrm{S} 1516-14392012005000057$

4. Nazari A (2013) Application of artificial neural networks for analytical modeling of Charpy impact energy of functionally graded steels. Neural Comput Appl 22:731-745. https://doi.org/10. 1007/s00521-011-0761-9

5. Bohlooli H, Nazari A, Kaykha MM (2013) RETRACTED: microhardness profile prediction of functionally graded steels by artificial neural networks. Int J Damage Mech 22(1):17-36. https:// doi.org/10.1177/1056789511432653

6. Nazari A, Khalaj G, Riahi S (2012) Application of ANFIS for analytical modeling of JIC of functionally graded steels. Math Comput Model 55(3-4):1339-1353. https://doi.org/10.1016/j. $\mathrm{mcm} .2011 .10 .013$

Publisher's Note Springer Nature remains neutral with regard to jurisdictional claims in published maps and institutional affiliations.
The original article can be found online at https:// doi.org/10.1007/s00521-012-0995-1.

A. Nazari

alinazari84@aut.ac.ir

1 Department of Materials Science and Engineering, Saveh Branch, Islamic Azad University, Saveh, Iran 